\title{
AN UNUSUAL CASE OF PAPILLARY THYROID CARCINOMA IODINE-131 AVID METASTASIS TO THE ADRENAL GLAND
}

\author{
Ivan Blažeković ${ }^{1}$, Tomislav Jukić ${ }^{1,2,3}$, Roko Granić ${ }^{1}$, Marija Punda ${ }^{1}$ and Maja Franceschi ${ }^{1,2,3}$
}
${ }^{1}$ Department of Oncology and Nuclear medicine, Sestre milosrdnice University Hospital Center, Zagreb, Croatia; ${ }^{2}$ School of Medicine, University of Zagreb, Zagreb, Croatia; ${ }^{3}$ Faculty of Medicine, Josip Juraj Strossmayer University of Osijek, Osijek, Croatia

\begin{abstract}
SUMMARY - Papillary thyroid carcinoma (PTC) is considered one of the most favorable tumors, indolent, with rare distant dissemination. Lungs and bones are the most common metastatic sites. Unusual sites of PTC distant metastases are extremely rare. Brain, liver, skin, kidney, pancreas, and adrenal gland PTC metastases have been sporadically reported in the literature. An 86-year-old female patient underwent total thyroidectomy and neck dissection due to PTC. Postoperative whole body iodine-131 scintigraphy with I-131 SPECT/CT of the abdomen revealed radioiodne avid left adrenal gland metastasis together with high postoperative serum thyroglobulin $(\mathrm{Tg})$ value of more than $5000 \mu \mathrm{g} / \mathrm{L}$ and high serum $\mathrm{Tg}$ antibodies. Considering the above-mentioned findings, patient's age and multiple comorbidities, radioiodine therapy was applied. PTC metastases to the adrenal gland are extremely rare, and to our knowledge, only nine cases have been reported in the literature. This case report complements rare examples of unusual PTC metastases.
\end{abstract}

Key words: Carcinoma, Papillary; Thyroid Neoplasms; Adrenal Gland Neoplasms; Single Photon Emission Computed Tomography Computed Tomography; Croatia; Iodine Radioisotopes

\section{Introduction}

Thyroid carcinoma is the most common endocrine tumor and the most common tumor site in women aged 10 to 29 years. The incidence increases with age reaching a peak in the 60 to 69 age group ${ }^{1}$. During the last few decades, the incidence of thyroid carcinoma has increased in Croatia, mostly due to the rise in the incidence of papillary thyroid carcinoma $(\mathrm{PTC})^{2}$, the most common type, comprising almost $90 \%$ of all thyroid cancer cases. Papillary TC is a relatively indolent, slow growing malignancy with an excellent overall prognosis. It typically remains limited to thyroid tissue or presents with metastases in regional lymph nodes.

Correspondence to: Maja Franceschi MD, PhD, Department of Oncology and Nuclear Medicine, Sestre milosrdnice University Hospital Center, Vinogradska c. 29, HR-10000 Zagreb, Croatia

E-mail: maja.franceschi@gmail.com

Received June 26, 2017, accepted August 25, 2017
Distant metastases are rare, typically in the lungs and bones as the most common metastatic sites ${ }^{3}$. Unusual sites of distant PTC metastases are extremely rare. Brain, liver, skin, kidney, pancreas, and adrenal gland PTC metastases have been sporadically reported in the literature ${ }^{4}$. Due to the almost anecdotal occurrence of PTC distant metastases in unexpected sites, there is a realistic possibility of diagnostic oversight and undercalling. It is important to emphasize the crucial role of radioiodine diagnostics with whole body iodine-131 scintigraphy (I-131 whole body scan, WBS), which is based on active tumor I-131 accumulation, conditioned by the presence of NaI symporter (NIS) in tumor cells. Furthermore, evaluation with I-131 single-photon emission computed tomography/computed tomography (SPECT/CT) imaging enables precise localization, and diagnostic specificity including exclusion of false-positive results ${ }^{5}$. In high-risk patients with suspected non-iodine avid metastases, 


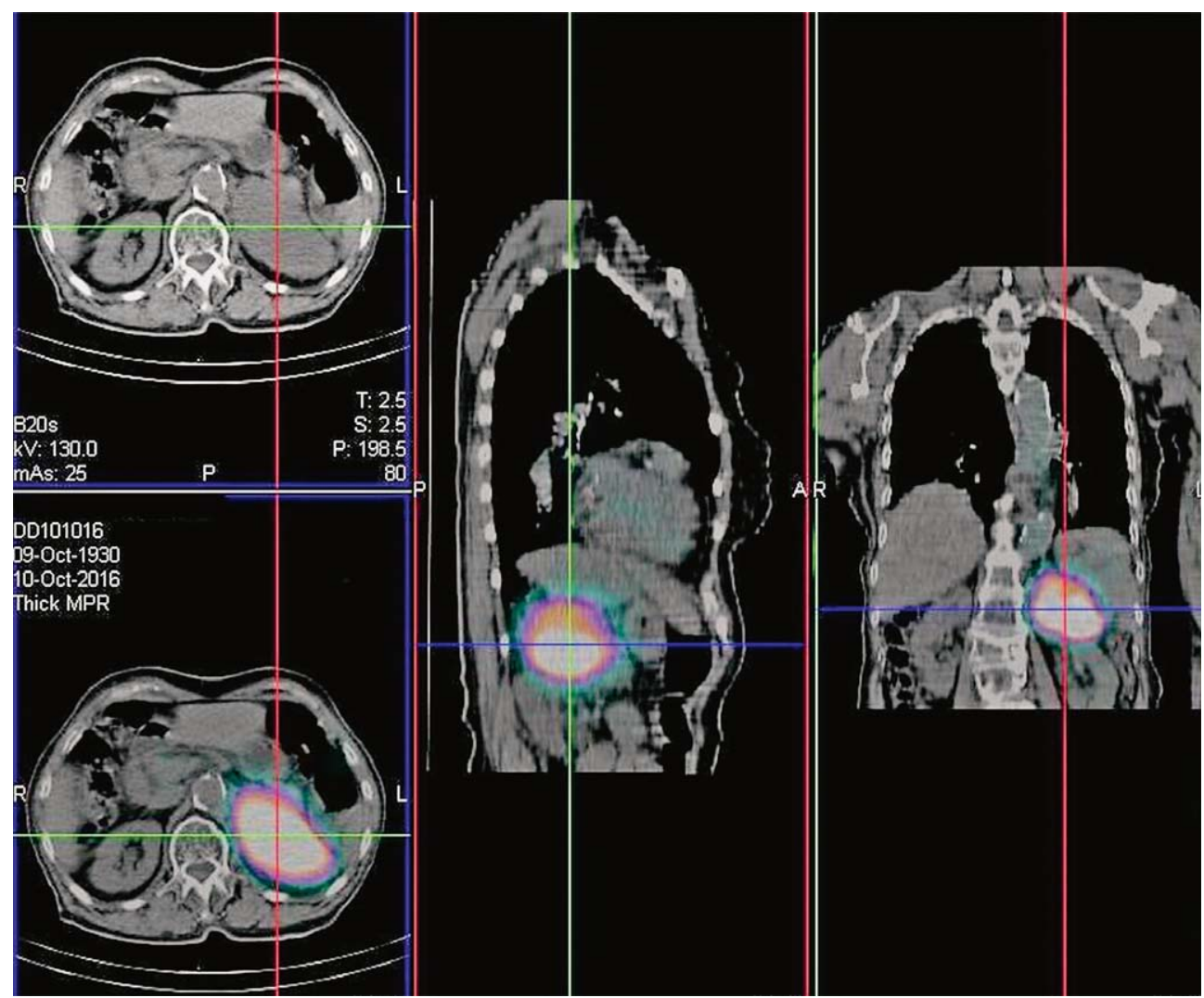

Fig. 1. SPECT/CT with I-131 of the thoracic and abdominal region demonstrates focal intense I-131 accumulation between the spleen and left kidney in the region of the left adrenal gland.

additional F-18-fluorodeoxyglucose (FDG)-positron emission tomography (PET)/CT imaging should be advocated.

\section{Case Report}

An 86-year-old female patient was admitted to the Sestre milosrdnice University Hospital Center due to vertigo, followed by nausea, vomiting and headache. Computed tomography of the brain was unremarkable. However, due to a $15 \mathrm{~kg}$ unintentional weight loss during the past year, further clinical workup including diagnostic imaging was performed. Cervical ultrasonography revealed nodules in both thyroid lobes and a suspicious $3 \mathrm{~cm}$ lymph node in region IV in the right side of the neck. Fine-needle aspiration biopsy identified PTC in the right thyroid lobe (Bethesda VI) and lymph node metastasis in region IV in the right side of the neck ${ }^{6}$. At the time of diagnosis, the patient was euthyroid. Total thyroidectomy with bilateral paratracheal (region VI) and right selective II-V neck dissection was performed. Final histopathologic findings were consistent with classic PTC American Joint Committee on Cancer (AJCC) stage T2N1bMx, including tumor nodule measuring $3.7 \times 2.5 \times 2.2 \mathrm{~cm}$ in size without extracapsular extension, one positive lymph node in the paratracheal right neck region VI and two positive lymph nodes in the dissected region IV of the right side of the neck (infiltrated with atypical epithelial cells of light cores with intranuclear inclusions and overlapping). A follicular adenoma of the left thyroid lobe, $1.8 \times 0.5 \mathrm{~cm}$ in size was also described. Dissected right neck regions II and III were histologically free of papillary TC. Postoperative oncologic examination detected high serum thyroglobulin ( $\mathrm{Tg}$ ) of more than $5000 \mu \mathrm{g} / \mathrm{L}$ with elevated $\mathrm{Tg}$ antibody titers (638.8 kIU/L; reference value < 115 kIU/L). Postoperative cervical ultrasonography was unremarkable, after which iodine-131 WBS was performed. Besides the expected smaller iodine-131 accumulation in the 


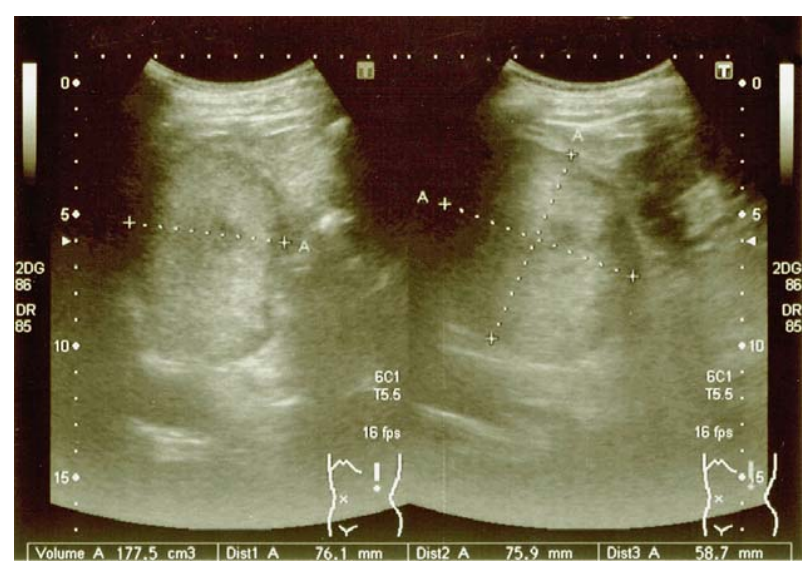

Fig. 2. Abdominal ultrasound performed one month after total thyroidectomy. Dimensions of the morphologically altered left adrenal gland were $76 \times 76 \times 59 \mathrm{~mm}$. treated with a $5809 \mathrm{MBq}\left(157 \mathrm{mCi}^{-}\right)$dose of iodine-131. Therapy was well tolerated and subsequently, the patient was started on suppressive L-T4 therapy. After radioiodine therapy, contrast enhanced arterial phase multi-slice computed tomography (MSCT) of the thoracic and abdominal region demonstrated an expansile left adrenal gland mass sized $7.8 \mathrm{~cm}$ in diameter with inhomogeneous contrast opacification, including a central low attenuation area of necrosis (Fig. 3). The patient's clinical condition improved significantly after radioiodine treatment. At first follow up with 131 WBS and I-131 abdominal SPET/CT, there was no interval growth of the left adrenal metastasis and no additional foci of abnormal radiotracer uptake to suggest disease progression. Further treatment op-

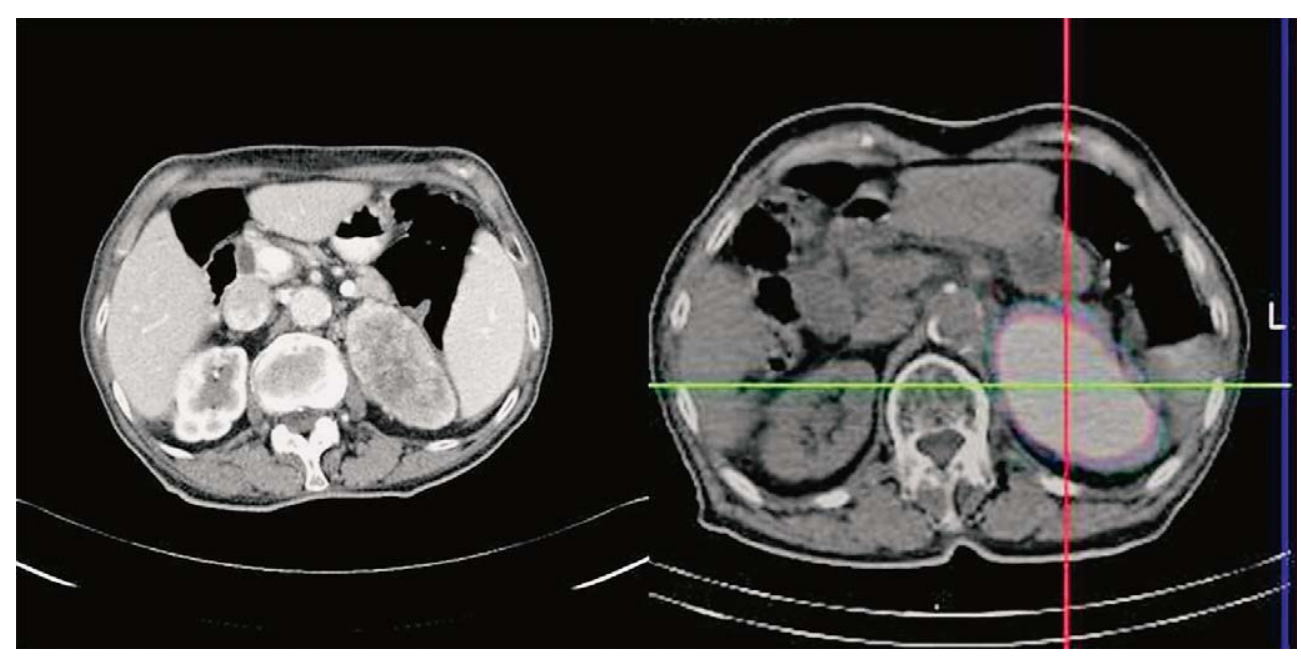

Fig. 3. Contrast enhanced arterial phase MSCT of the abdominal region demonstrates soft tissue mass in the left adrenal gland accompanied by radioiodine accumulation on I-131 SPECT/CT.

thyroid bed region, there was intense large focal I-131 accumulation in the upper left quadrant of the abdomen. Therefore, additional I-131 SPECT/CT of the thorax and abdomen was performed, which demonstrated avid I-131 accumulation measuring $8 \times 6 \mathrm{~cm}$ in size located in the region of the left adrenal gland, highly indicative of iodine-131 avid PTC metastasis (Fig. 1). In addition, ultrasound examination of the abdominal region was performed showing a solid mass measuring $76 \times 76 \times 59 \mathrm{~mm}$, located between the spleen and the left kidney (Fig. 2). Based on the above-mentioned findings, due to the age and poor overall condition including multiple comorbidities, the patient was tions will be considered, including surgery or additional iodine-131 therapy.

\section{Discussion}

Despite the characteristic features of PTC as an indolent and prognostically extremely favorable neoplasm, it is important to emphasize the possibility of rare and unexpected metastases at unusual sites. According to the available data, a total of nine cases of PTC metastases in the adrenal gland have been described in the literature ${ }^{7}$, highlighting the importance and uniqueness of the case presented. In 2001, the first 
known case was reported in the literature as unilateral PTC metastasis in the adrenal gland 8 . In 2013, for the first time bilateral adrenal PTC metastases were described $^{9}$. In our case, a radioiodine avid left adrenal gland metastasis was suspected on iodine $131 \mathrm{WBS}$ and confirmed by additional I-131 SPECT/CT imaging. Besides thyroid tissue and differentiated thyroid carcinoma, NIS is also physiologically expressed in the stomach, salivary glands and lactating breast tissue. Additional tissues such as the heart, thymus, pancreas, lungs and even adrenal glands may express NIS occasionally ${ }^{10}$. Therefore, the possibility of a false-positive finding should be excluded ${ }^{11}$. However, high serum $\mathrm{Tg}$ level in conjunction with focal, intense unilateral I-131 accumulation in the projection of the left adrenal gland and visible anatomical structural changes including abnormal parenchymal enhancement of the left adrenal gland on arterial phase contrast-enhanced MSCT further supported the diagnosis of PTC metastasis. Despite the tendency of loco-regional lymphatic dissemination of PTC, the highlighted finding of a distant metastasis in the adrenal gland stresses the importance of greater attention in the search for distant metastases. This case report complements rare examples of unusual metastases of PTC. Although these metastases are extremely rare, the possibility of their occurrence should be taken in consideration in the appropriate clinical setting.

\section{References}

1. Hrvatski zavod za javno zdravstvo, Registar za rak Republike Hrvatske. Incidencija raka u Hrvatskoj 2014., Bilten 39, Zagreb, 2016. (in Croatian)
2. Vučemilo L, Znaor T, Kuliš T, Šekerija M, Znaor A. Thyroid cancer incidence and mortality trends in Croatia 1988-2010. Acta Clin Croat. 2015;54(1):30-7.

3. Mazzaferri EL, Kloos RT. Clinical review 128: current approaches to primary therapy for papillary and follicular thyroid cancer. J Clin Endocrinol Metab. 2001;86(4):1447-63, https://doi.org/10.1210/jcem.86.4.7407

4. Farina E, Monari F, Tallini G, Repaci A, Mazzarotto R, Giunchi $\mathrm{F}$, et al. Unusual thyroid carcinoma metastases: a case series and literature review. Endocr Pathol. 2016;27(1):55-64, https://doi.org/10.1007/s12022-015-9410-7

5. Glazer DI, Brown RK, Wong KK, Savas H, Gross MD, Avram AM. SPECT/CT evaluation of unusual physiologic radioiodine biodistributions: pearls and pitfalls in image interpretation. Radiographics. 2013;33(2):397-418, https://doi.org/10.1148/rg.332125051

6. Cibas ES, Ali SZ, NCI Thyroid FNA State of the Science Conference. The Bethesda System for Reporting Thyroid Cytopathology. Am J Clin Pathol. 2009;132(5):658-65, https://doi.org/10.1309/AJCPPHLWMI3JV4LA

7. Madani A, Jozaghi Y, Tabah R, How J, Mitmaker E. Rare metastases of well-differentiated thyroid cancers: a systematic review. Ann Surg Oncol. 2015;22(2):460-6, https://doi.org/10.1245/s10434-014-4058-y

8. Koutkia P, Safer JD. Adrenal metastasis secondary to papillary thyroid carcinoma. Thyroid. 2001;11(11):1077-9, https://doi.org/10.1089/105072501753271798

9. Batawil N. Papillary thyroid cancer with bilateral adrenal metastases. Thyroid. 2013;23(12):1651-4, https://doi.org/10.1089/thy.2013.0065

10. Penheiter AR, Russell SJ, Carlson SK. The sodium iodide symporter (NIS) as an imaging reporter for gene, viral, and cellbased therapies. Curr Gene Ther. 2012;12(1):33-47, https://dx.doi.org/10.2174\%2F156652312799789235

11. Jong- Ryool O, Byeong-Cheol A. False-positive uptake on radioiodine whole-body scintigraphy: physiologic and pathologic variants unrelated to thyroid cancer. Am J Nucl Med Mol Imaging. 2012;2(3):362-85. 
Sažetak

\section{NEOBIČNO MJESTO PRESADNICE PAPILARNOG KARCINOMA ŠTITNJAČE U NADBUBREŽNU ŽLIJEZDU: PRIKAZ SLUČAJA}

\section{Blažeković, T. Jukić, R. Granić, M. Punda i M. Franceschi}

Papilarni karcinom štitnjače svrstava se u maligne tumore s najpovoljnijom prognozom, polaganog je rasta, a presadnice na udaljenim mjestima su rijetke. Najčešća mjesta udaljene diseminacije papilarnog karcinoma štitnjače su pluća i kosti. Rijetka mjesta udaljene diseminacije opisana u literaturi su mozak, jetra, koža, gušterača i nadbubrežna žlijezda. Bolesnica u dobi od 86 godina operirana je zbog papilarnog karcinoma štitnjače. Nakon operativnog odstranjenja štitnjače s tumorom i disekcije vrata učinjena je poslijeoperacijska onkološka obrada uključujući scintigrafiju cijelog tijela jodom-131 uz SPECT/CT abdomena. U području lijeve nadbubrežne žlijezde zabilježena je intenzivna nakupina joda-131 koja je odgovarala presadnici papilarnog karcinoma štitnjače. Serumska vrijednost tumorskog biljega tireoglobulina bila je izrazito povišena i iznosila je više od $5000 \mu \mathrm{g} / \mathrm{L}$ uz pozitivna antitireoglobulinska protutijela. Uzevši u obzir nalaze poslijeoperacijske onkološke obrade, dob i opće loše stanje bolesnice provedeno je liječenje jodom-131. Presadnice papilarnog karcinoma štitnjače u nadbubrežnu žlijezdu su iznimno rijetke i dosad je u literaturi opisano samo 9 slučajeva. Ovaj prikaz bolesnice upotpunjuje dosadašnje rijetke slučajeve neobičnih mjesta udaljene diseminacije papilarnog karcinoma štitnjače.

Ključne riječi: karcinom, papilarni; tireoidni tumori; nadbubrežna žlijezda, tumori; jednofotonska emisijska-kompjutorizirana tomografija; Hrvatska; jod, radioizotopi 